\title{
Shifting sands: a paradigm change in the development discourse on women's human rights and empowerment
}

\author{
Catherine Klirodotakou
}

International human rights declarations, conventions and protocols such as the Universal Declaration of Human Rights (UDHR) and the Convention on the Elimination of All Forms of Discrimination against Women (CEDAW), are universally recognised as constituting the basis for demanding and achieving gender equality. They 'set a vision of a world where there is justice' (Cornwall 2015) and today it is widely acknowledged that the normative approach to development should be rights based, even if it's not the norm in practice. This discord is particularly evident in the women's rights development discourse. Securing women's empowerment has increasingly been dominating the international development agenda, but many consider the model being disseminated as de-radicalised, removed from its feminist activist roots and pursuing an apolitical ideology (Cornwall and Molyneux 2006). This in turn promotes and supports a very narrow definition of empowerment; one that does not seek wholesale substantive and transformative change for women and society, but seems to be content to work within and even embrace the existing socio-economic framework.

\section{A blueprint for securing rights and empowerment}

2015 marks the 20th anniversary of the adoption of the Beijing Declaration and Platform for Action (BPfA). It was and remains a bold and progressive blueprint, drafted and agreed by 189 governments, to advance women's rights and empowerment globally. It ushered in an era of important global pacts such as the United Nations Security Council Resolution 1325 (2000), which recognised the impact of conflict on women, and their central role in building peace. However, despite this progress, the world has changed significantly since the adoption of the BPfA; conflict, extremism, climate change, natural disasters and the global financial crisis, to name but a few, have all contributed to a climate in which there are growing attempts to water down previously 
agreed international obligations and commitments. Perversely, this threat comes at a time when women's empowerment has never been more popular with governments, donors and civil society organisations alike. The prevailing rhetoric is that women's human rights, women's empowerment and gender equality are central to the international development agenda.

\section{New actors but a shrinking space}

Women - and girls in particular - seem to be the panacea to all our development woes. Get more women into the workplace and your economy will be thriving; educate girls and the whole community prospers; turn women into politicians and peace and security will prevail. One would consider this a victory: women's rights are finally on the agenda like never before, but there is something not quite right with this picture. We are witnessing an era where the agents of this change are not women themselves and women's rights organisations, but increasingly mainstream international development agencies and multilateral and bilateral development institutions. The women's rights movement - which was key to raising consciousness and building momentum for gender equality in the past - is not driving this process. Many may consider that this is how it should be: women's human rights and gender equality should not be the domain of the few but be embraced, supported and mainstreamed. But this mainstreaming of the women's human rights and gender equality is going hand in hand with a fundamental shift in what is considered and practiced as empowerment; both as a goal in itself and as a process.

Critics of this agenda view efforts to secure women's human rights and empower women as increasingly being co-opted into an instrumentalist, apolitical, results-based, cause and effect paradigm. In short, securing women's rights becomes a means to tackle poverty under a neoliberal economic model. In this scenario violence and discrimination against women become bitesize tangible dilemmas, which are compartmentalised and tackled in time-bound projects. Andrea Cornwall (2007) has coined this type of piecemeal approach to development as empowerment lite - the focus is on numbers, alleviating the symptoms of poverty and oppression, but not addressing the power imbalance nor contributing to any meaningful transformative empowerment for women. A form of empowerment lite in action can be seen in the Millennium Development Goal 3 (MDG3), ${ }^{1}$ which focussed on a narrow definition of empowerment; one based on education, employment and political participation and did little to

1 The Millennium Development Goals are the eight international development goals to be achieved by 2015, that were established following the Millennium Summit of the United Nations in 2000, following the adoption of the United Nations Millennium Declaration. MDG3 is to 'promote gender equality and empower women'. 
consider the multi-dimensional aspect of inequality, how to address patriarchy, or pursue transformative forms of women's agency (Kabeer 2005).

\section{Challenging patriarchy, transforming societies}

Reclaiming the discourse on empowerment as a way to challenge patriarchy, transform the structures and institutions that reinforce and perpetuate discrimination and inequality, and enable women to gain access to, and control of, resources (Batliwala 1994) is one of the biggest challenges we face as women's rights activists and practitioners. Having frameworks to call States and other duty bearers to account is an important platform that underpins the work of women's rights organisations. The lack of commitment towards substantive progress on achieving women's human rights, however, is impeding efforts in securing long-term transformational changes in the lives of women and girls. The increasing instrumentalist focus on women as a means to an end and the overwhelming focus to articulate poverty and inequality as one-dimensional cause and effect, reflects a de-politicisation of women's empowerment and gender equality. Increasingly women's rights organisations are facing the dilemma of either adapting to this paradigmatic shift or potentially facing extinction.

\section{The de-politicisation of securing women's rights}

In this context it has become increasingly hard to articulate women's inequality and discrimination as manifestations of power over access to and control of resources. Legal reform alone is not enough to tackle social norms, attitudes and practices that perpetuate women's subordination and projects that do not take a holistic approach to addressing violence, discrimination and inequality cannot bring about substantive changes in securing women's rights. For instance, women's rights organisations in Ghana such as the Gender Studies and Human Rights Documentation Centre and Women in Law and Development in Africa, recognise that quotas alone will not get more women into politics, and that there is a need to work at different levels from the personal to the international. Their approach looks at creating women only or safe spaces for women, to gain confidence, skills and knowledge, before they even start to consider taking on leadership positions. Simultaneously they recognise the need to create an enabling environment which accepts and supports women's participation and they do that by engaging with different actors such as traditional leaders, community members, local authorities, the media and politicians. What these organisations inherently understand is that unless they tackle structural inequality and focus on women's voice and agency, then any gains will be short lived and will not contribute to a transformation of society.

A recent study has reaffirmed the catalytic role that women's rights organisations play in such interventions. The four-decade research programme 
which looked at 70 countries found that the mobilisation of women's organisations and movements is more important for combating violence against women than the wealth of nations, left-wing political parties, or the number of women politicians (Htun and Weldon 2012). Yet despite such evidence there are numerous examples of the disparity between rhetoric and practice. In Sierra Leone a local women's rights organisation lost vital funding from an international NGO when they chose to support a mainstream civil society organisation instead, to deliver work on addressing violence against women and girls (VAWG). Two years later that same INGO, which considers women's rights one of its main areas of work, profiled their ex-partner in a report about the increasing marginalisation of women's rights organisations.

One Zimbabwean women's rights organisation - recognised internationally for its efforts to address women's civil and political participation - described how they are increasingly being forced into carrying out work that takes a power and even gender neutral approach to tackling women's exclusion. They see the personal transformation element of their approach as key, but donors seem not to. Building a strong sense of self and agency in women appears not to be easily measurable and not immediately clear as to how it contributes to good governance. Instead their work has to be framed in demanding provision of basic social services and livelihood skills development. The rhetoric appears to be apolitical; poverty and exclusion are presented as a product of women not being economically empowered, thus all women need is access to resources and the rest will follow - seemingly a win-win for development and for women. But we need to be questioning whether these are mutually reinforcing. Despite evidence pointing to the need to collectively address empowerment, equality and rights, there are numerous examples of empowerment initiatives that circumvent the other two. Take Water, Sanitation and Hygiene (WASH) programmes for instance: in recent years they have been increasingly presented as a means to reduce VAWG. Resources are being poured into this type of work, despite evidence pointing to the fact that there is no tangible reduction in VAWG (Fulu, Kerr-Wilson, and Lang 2014).

\section{5 and beyond}

In the Sustainable Development Goals, which will replace the MDGs in 2016, we have an opportunity to try to redress the situation and bring power back into empowerment work. A strong commitment to human rights is key but within a framework that seeks transformation and is robust enough to address the deep rooted and persistent structural gender inequalities that exist. Women's rights organisations need to be in the driving seat and the development agenda must meet the actual needs and concerns of women at the local level. It has to recognise that in today's globalised world there are new actors, such as transnational corporations, financial institutions and private 
foundations, that we need to be demanding accountability from and it has to foster women's collective action to monitor and remedy the shifting sands of the rights and development discourse. This means reclaiming Batliwala's (1994) notion of empowerment of challenging patriarchy, transforming structures and institutions and enabling women to gain access to, and control of, resources.

\section{Bibliography}

Batliwala, S. (1994) 'The meaning of women's empowerment: new concepts from action', in G. Sen, A. Germain and L. C. Chen (eds.), Population Policies Reconsidered: Health, Empowerment and Rights (Cambridge: Harvard University Press).

Cornwall, A. and M. Molyneux (2006) 'The politics of rights: dilemmas for feminist praxis', Third World Quarterly 27 (7), pp. 1175-91.

Cornwall, A. (2007) 'Pathways of women's empowerment', in 50.50 Inclusive Democracy (30 July 2007), available at https://www.opendemocracy.net/ article/pathways_of_womens_empowerment (accessed 10 Sept. 2015).

- (2015) 'Why gender equality by numbers will never measure up', The Guardian (26 March 2015), available at http://www.theguardian.com/ global-development $/ 2015 / \mathrm{mar} / 26 /$ why-gender-equality-by-numbersnever-measure-up-mdg3-stereotypes (accessed 10 Sept. 2015).

Fulu, E., A. Kerr-Wilson and J. Lang (2014) 'What works to prevent violence against women and girls? Evidence review of interventions to prevent violence against women and girls', in DFID Violence against women and girls guidance notes (30 July 2014), available at https://www.gov.uk/ government/publications/what-works-in-preventing-violence-againstwomen-and-girls-review-of-the-evidence-from-the-programme (accessed 10 Sept. 2015).

Htun, M. and L. Weldon (2012) 'The civic origins of progressive policy change: combating violence against women in global perspective, 19752005', American Political Science Review 106 (3), pp. 548-69.

Kabeer, N. (2005) 'Gender equality and women's empowerment: a critical analysis of the third millennium development goal 1', Gender \& Development 13 (1), pp. 13-24. 